\title{
Comparative evaluation of INNO-LiPA HBV assay, direct DNA sequencing and subtractive PCR-RFLP for genotyping of clinical HBV isolates
}

\author{
Maisa M Ali*1,4, Fuad Hasan2,3,4, Suhail Ahmad1,4 and Widad Al-Nakib1,4
}

\begin{abstract}
Genotypes (A to H) of hepatitis B virus (HBV) influence liver disease progression and response to antiviral therapy in HBV-infected patients. Several methods have been developed for rapid genotyping of HBV strains. However, some of these methods may not be suitable for developing countries. The performance of INNO-LiPA HBV Genotyping assay (LiPA), direct DNA sequencing and subtractive PCR-RFLP of genotype-specific HBV genome regions were evaluated for accurately determining the HBV genotypes by analyzing sera $(n=80)$ samples from chronic HBV patients. Both, LiPA and DNA sequencing identified 63, 4 and $13 \mathrm{HBV}$ strains as belonging to genotype $D$, genotype $A$ and mixed genotype $A$ and D, respectively. On the contrary, the PCR-RFLP-based method correctly identified all 4 genotype A but only 56 of 63 genotype D strains. Seven genotype D strains yielded indeterminate results. DNA sequence comparisons showed that a single nucleotide change in the target region generated an additional restriction site for N/a IV that compromised the accuracy of this method. Furthermore, all the mixed genotype A and D strains were identified only as genotype A strains. The data show that the PCR-RFLP-based method incorrectly identified some genotype D strains and failed to identify mixed genotype infections while LiPA and DNA sequencing yielded accurate results.
\end{abstract}

\section{Findings}

Eight distinct genotypes (A to $\mathrm{H}$ ) of hepatitis B virus (HBV) have been identified and their occurrence exhibits distinct preferences for ethnic origin of the patient and/or geographic regions of the world [1,2]. Recent studies have shown that HBV genotypes influence liver disease progression, selection of mutants and response to antiviral therapy in acute and chronic HBV infections [3-5]. Considering the importance of determining the HBV genotype, several methods have been developed for genotyping of HBV strains [6]. A PCR-RFLP-based method that involves successive digestion of amplicon with a battery of restriction enzymes to discriminate the individual genotypes is most suitable for developing countries. However, there is very limited data on its performance in different countries/geographical settings $[7,8]$. A commercially available reverse hybridization-

\footnotetext{
* Correspondence: maisa_ali@ymail.com

1 Department of Microbiology, Faculty of Medicine, Health Sciences Center, Kuwait University, Kuwait

Full list of author information is available at the end of the article
}

based line probe assay (INNO LiPA HBV Genotyping assay, LiPA) is easy to perform and is also suitable for detecting mixed genotype infections [9]. Despite these advantages, the test is fairly expensive for resource-poor countries. Direct DNA sequencing of PCR generated amplicons corresponding to genotype-specific regions of HBV genome also yields accurate genotype assignments and is the method of choice for patients infected with recombinant genotypes $[9,10]$. However, DNA sequencing is still considered as technically demanding, time consuming and costly in most of the developing countries. This study was carried out to evaluate the performance of three (LiPA, direct DNA sequencing and subtractive PCR-RFLP) genotyping methods to determine the method most suitable for routine use in a developing country. The comparative performance of the three methods was tested by using 80 consecutive HBV-DNA positive serum samples obtained from chronic HBV patients. The study was approved by the Committee for the Protection of Human Subjects in Research, Faculty of Medicine, Kuwait University. The HBV DNA was isolated 
from blood samples by using High Pure Template Preparation Kit (Roche Applied Science, Germany) according to the kit instructions. The final pellet was resuspended in $100 \mu \mathrm{l}$ of pre-heated elution buffer and $10 \mu \mathrm{l}$ was used as a template for HBV DNA amplification. The LiPA kits were obtained from Innogenetics (Belgium) and were used according to the instructions supplied with the kit. Briefly, the HBV DNA was amplified by nested PCR, the amplicons were hybridized to genotype-specific probes impregnated on membrane strips and the hybrids were detected with chromogenic substrates. The LiPA results were interpreted as instructed by the kit's manufacturer. The genotype-specific segment of the HBV polymerase gene was amplified and sequenced for DNA sequencebased determination of specific HBV genotypes exactly as described previously [10]. The subtractive PCR-RFLPbased genotyping was performed by semi-nested PCR amplification of a $485 \mathrm{bp}$ fragment which was successively digested with 5 restriction enzymes (in separate tubes) to identify genotype-specific sequences exactly as described earlier [8]. For isolates giving aberrant results, the amplicons were cloned in pGEM-T Easy plasmid as described previously [11]. In each case, the plasmid DNA was isolated from 10 independent clones of Escherichia coli by a modified alkaline lysis procedure [12] and sequenced by using quick start cycle DNA sequencing kit (Beckman-Coulter). The DNA sequencing was performed as described in detail previously [13,14]. The LiPA identified 63 and four HBV strains as belonging to genotype D and genotype A, respectively. Thirteen HBV strains yielded amplicons that hybridized to probe primers specific for both, genotype A and genotype D, and were thus identified as mixed genotype A and D strains. The DNA sequencing data of genotype-specific region of HBV polymerase gene correlated completely with the genotype assignment obtained with LiPA for all the 80 strains. The results are consistent with earlier reports showing the ability of the LiPA to detect mixed genotype infections $[9,15,16]$. The comparative analyses of DNA sequence data for all genotype D strains in Kuwait (data from 10 selected isolates are shown in Figure 1) identified a unique signature of AA dinucleotide at position 204 and 205 in the HBV polymerase gene. This signature sequence is not only absent in representative genotype $\mathrm{D}$

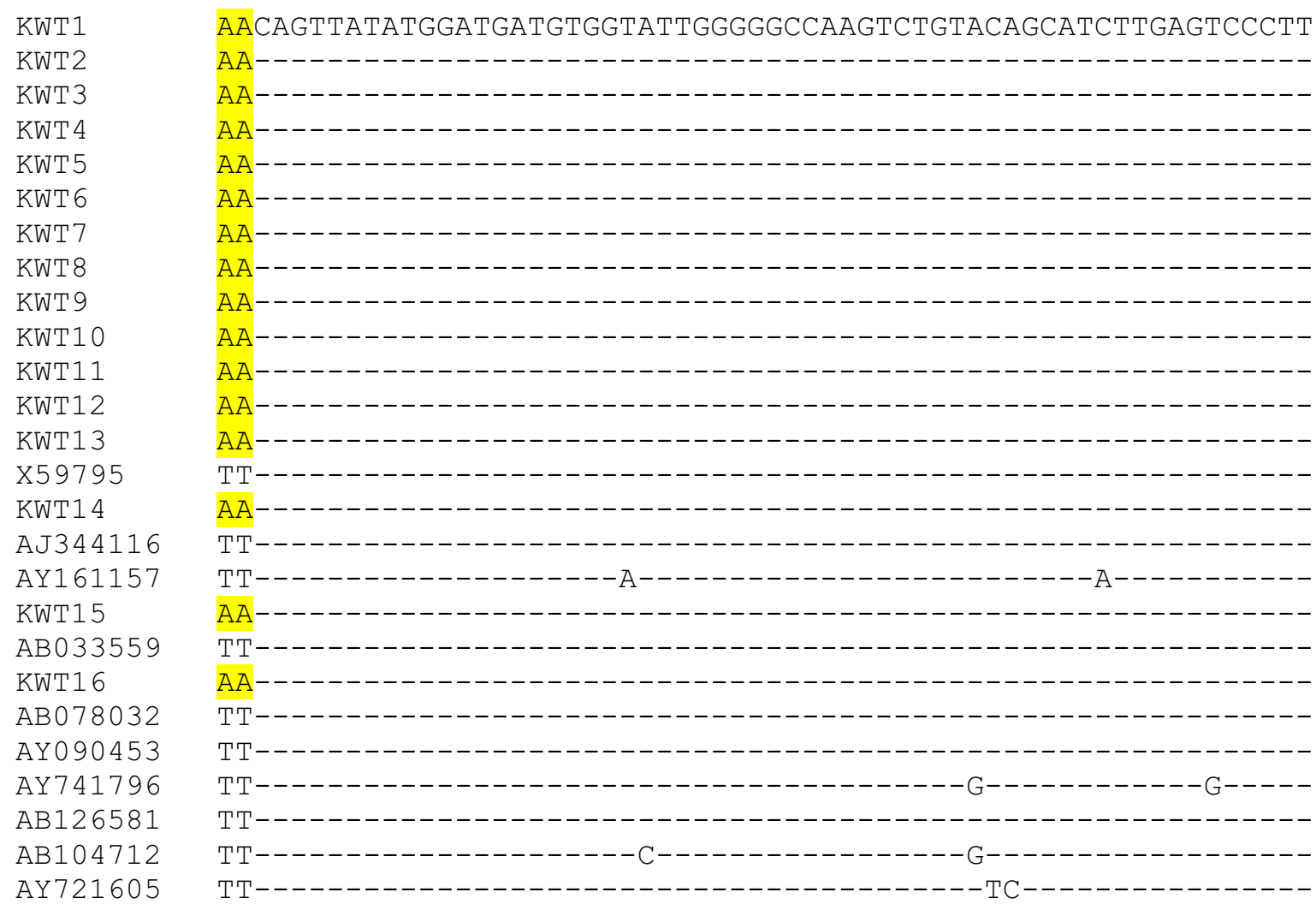

Figure 1 Alignment of nucleotide sequences of the HBPol gene product of HBV genotype D. A-to-T nucleotide substitution occurred at nt 204 in all HBV Kuwaiti isolates (KWT1-16). These substitutions represent unique signature sites for local HBV genotype D isolates (shaded). Representative sequences of genotype D are shown (ㄷ9795-ITALY, AJ344116-FRANCE, AY161157-INDIA, AB033559-PAPUA, AB078032-JAPAN, AY090453-SWEDEN, AY741796-IRAN, AB126581-RUSSIA, AB104712-EGYPT and AY721605-TURKEY). 
strains isolated in Italy, France, Russian Federation, Sweden, India, Japan and Papua New Guinea [GenBank: $\underline{X 59795}, \underline{A J 344116}, \underline{A B 126581}, \underline{A Y 090453}, \underline{A Y 161157}$, AB078032 and AB033559; respectively] but also from several Middle Eastern countries such as Iran, Egypt and Turkey [17-19] (Figure 1). Since the genotype-specific region of the $\mathrm{HBV}$ polymerase gene overlaps with the surface antigen of the HBV (HBsAg), the sequencing data can also be used to deduce the "a" determinant (amino acids 124-147) of the S-gene specifying all the subtypes [20]. Based on these analyses, three genotype D strains displayed unusual amino acid substitutions. Two isolates shared the amino acid pattern Arg $^{122}$, Pro ${ }^{127}$ and Ser ${ }^{140}$ specifying ayw subtype with unique amino acid substitution involving residue 134 ( $\mathrm{Ile}^{134}$ or $\mathrm{Asn}^{134}$ ). The remaining strain contained unique amino acid substitution at codon 127 (Asn $\left.{ }^{127}\right)$. Furthermore, all the mixed genotype $A$ and D strains were untypeable, as expected. The subtractive PCR-RFLP-based assay showed that none of the strains belonged to genotype $\mathrm{C}, \mathrm{B}, \mathrm{E}$ or F. Following Nla IV digestion, the $220 \mathrm{bp}$ fragment characteristic for genotype A was observed with $17 \mathrm{HBV}$ strains. Four of these strains were identified as belonging to genotype A by LiPA or DNA sequencing while the remaining 13 strains were identified as mixed genotype A and D strains by the other two genotyping methods. The data showed that the
KWT -43

$\mathrm{X} 65259$

$\times 75669$

KWT -43

$\times 65259$

$\times 75669$

KWT -43

X65259

$\times 75669$

KWT -43

X65259

$\times 75669$

KWT -43

X65259

$\times 75669$

$\mathrm{KWT}-43$

X65259

$\times 75669$

KWT -43

$\times 65259$

$\times 75669$

KWT -43

$\mathrm{X} 65259$

$\times 75669$

\section{CCGCAGAGTCTAGACTCGTGGTGGACTTCTCTCAATTTTCTAGGGGGAACCACCGTGTGT 300}
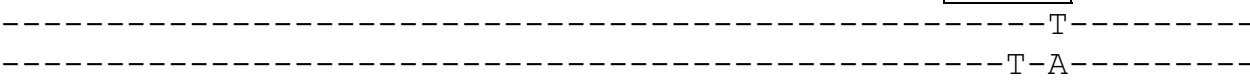

CTTGGCCAАAАTTCGCAGTCCCCAАCCTCCAАTCACTCACCAАCСTCTTGTCCTCCAACT
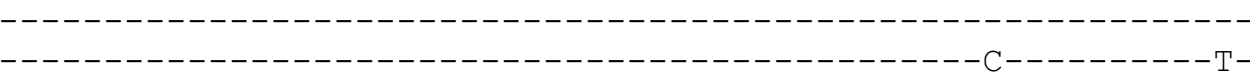

TGTCCTGGTTATCGCTGGACGTGTCTGCGGCGTTTTATCATCTTCCTCTTCATCCTGCTG
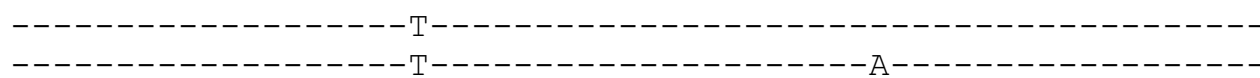

CTATGCCTCATCTTCTTGTTGGTTCTTCTGGACTATCAAGGTATGTTGCCCGCTTGTCCT --------------------------------------------------- T-------

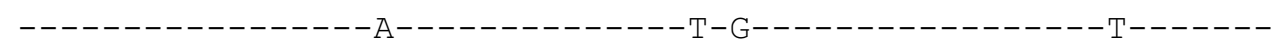

CTAATTCCAGGATCTTCAACAACCAGCACGGGACCATGCAGAACCTGCACGACTCCTGCT

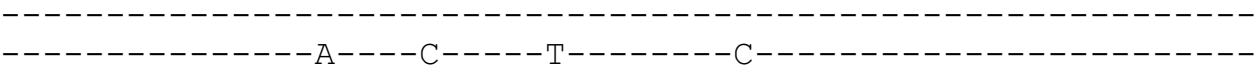

CAAGGAACCTCTATGTATCCCTCCTGTTGCTGTACCAAACCTTCGGACGGAAATTGCACC

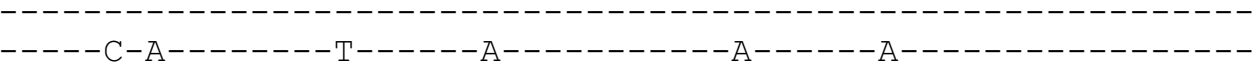

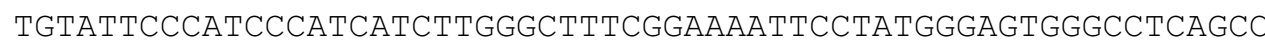


PCR-RFLP-based method detected Genotype A status of all HBV strains whether due to monoinfection with Genotype A $(\mathrm{n}=4)$ or due to mixed Genotype A and D infection $(n=13)$. Only 56 of the remaining 63 strains yielded a $186 \mathrm{bp}$ fragment characteristic for genotype $\mathrm{D}$ following restriction digestion with Nla IV while the remaining seven strains yielded atypical RFLP patterns (a 220 bp fragment was present in addition to the expected $186 \mathrm{bp}$ fragment) (data not shown). The $485 \mathrm{bp}$ fragment from all the seven isolates was, therefore, cloned in pGEM-T Easy plasmid and 10 independent recombinant plasmids for each HBV strain were sequenced. The DNA sequencing data showed that all the seven strains contained a $\mathrm{T}$ to C nucleotide substitution at nucleotide position 291 that generated a new recognition site of Nla IV within the larger (265 bp) fragment that is ordinarily released following Nla IV digestion of 485 bp amplicon from genotype D strains (Figure 2). Thus, the presence of an additional restriction site for Nla IV, resulting in further digestion of $265 \mathrm{bp}$ fragment into $41 \mathrm{bp}$ and $224 \mathrm{bp}$ fragments, yielded aberrant results by PCR-RFLP-based method. These findings are similar to an earlier report from Uzbekistan. The PCR-RFLP-based assay yielded aberrant results for five of $54 \mathrm{HBV}$ strains [7]. Similar to the results reported in this study, their DNA sequencing data for two of the five strains also confirmed the presence of $\mathrm{T}$ to $\mathrm{C}$ substitution at the same site that generated an additional restriction site for Nla IV [7]. In conclusion, the results of this study showed that subtractive PCRRFLP-based genotyping of HBV strains is simple to perform and accurately detected genotype assignment of a substantial number (60 of 80) of HBV strains. Additionally, the PCR-RFLP-based method also detected the Genotype A in all 13 mixed Genotype A and D strains of HBV. On the other hand, despite being costly or technically demanding, LiPA and direct DNA sequencing yielded accurate identification of all genotype $\mathrm{A}$ and genotype D and mixed genotype A and D strains of HBV. The DNA sequencing data reported in this study have been submitted to [GenBank under accession numbers: $\underline{\mathrm{AM} 279420}$ to $\underline{\mathrm{AM} 279439]}$.

\section{Competing interests}

The authors declare that they have no competing interests.

\section{Authors' contributions}

MMA, FH, SA and WAN designed the study and FH collected the specimens. MMA carried out the DNA Extraction, INNO-LiPA genotyping assay, Direct DNA Sequencing, PCR-RFLP studies, sequence alignments and analysis. SA participated in the sequence alignment analysis. All authors contributed in manuscript writing, read and approved the final manuscript.

\section{Acknowledgements}

This study was supported by Research Administration grant YM 02/03 and the College of Graduate Studies, Kuwait University.

\section{Author Details}

'Department of Microbiology, Faculty of Medicine, Health Sciences Center, Kuwait University, Kuwait, ${ }^{2}$ Department of Medicine, Faculty of Medicine, Health Sciences Center, Kuwait University, Kuwait, ${ }^{3 G}$ Gastroenterology Unit, Mubarak Al-Kabeer Teaching Hospital, Ministry of Health, Kuwait and ${ }^{4}$ Genetics \& Genomics Research Unit, Biomedical Research Department, Dasman Diabetes Institute, P.O. Box: 1180 Dasman 15462, Kuwait

Received: 12 April 2010 Accepted: 30 May 2010

Published: 30 May 2010

\section{References}

1. Norder H, Courouce A, Coursaget P, Echevarria JM, Lee SD, Mushahwar IK, Robertson BH, Locarnini S, Magnius LO: Genetic diversity of hepatitis B virus strains derived worldwide: genotypes, subgenotypes and HBsAg subtypes. Intervirology 2004, 47:289-309.

2. Schaefer S: Hepatitis B virus: significance of genotypes. J Viral Hepat 2005, 12:111-124.

3. Baumert $T$, Thimme R, Weizsacher F: Pathogenesis of hepatitis B virus infection. World J Gastroentero/ 2007, 13:82-90.

4. But D, Lai C, Yuen M: Natural history of hepatitis-related hepatocellular carcinoma. World J Gastroenterol 2008, 14:1652-1656.

5. Sumi H, Yokosuka O, Seki N, Arai M, Imazeki F, Kurihara T, Kanda T, Fukai K, Kato M, Saisho H: Influence of hepattis B virus genotypes on the progression of chronic type B liver disease. Hepatology 2003, 37:19-26

6. Bartholomeusz A, Schaefer S: Hepatitis B virus genotypes: comparison of genotyping methods. Rev Med Virol 2004, 14:3-16.

7. Kato H, Ruzibakiev R, Yuldasheva N, Hegay T, Kurbanov F, Achunfjanov B, Tuichiev L, Usuda S, Ueda R, Mizokami M: Hepatitis B virus genotypes in Uzbekistan and validity of two different systems for genotyping. J Med Virol 2002, 67:477-483.

8. Mizokami M, Nakano T, Orito E, Tanaka Y, Sakugawa H, Mukaide M, Robertson $\mathrm{BH}$ : Hepatitis $\mathrm{B}$ virus genotype assignment using restriction fragment length polymorphism patterns. FEBS Lett 1999, 450:66-71.

9. Osiowy C, Giles E: Evaluation of the INNO-LiPA HBV genotyping assay for determination of hepatitis B virus genotype. J Clin Microbiol 2003, 41:5473-7.

10. Novoa SR, Tato AG, Guirao AA, Castroagudin J, Quintela AG, Riestra CG, Regueiro $B$ : Hepatitis $B$ virus genotyping based on cluster analysis of the region involved in lamivudine resistance. J Virol Meth 2004, 115:9-17.

11. Ahmad S, Ali MM, Mustafa AS: Construction of a modified vector for efficient purification of recombinant Mycobacterium tuberculosis proteins expressed in Escherichia coli. Protein Expr Purif 2003, 29:167-175

12. Ahmad S, Glavas NA, Bragg PD: A mutation at the Gly314 of the $\beta$ subunit of the Escherichia coli pyridine nucleotide transhydrogenase abolishes activity and affects the NADP(H)-induced conformational change. Eur J Biochem 1992, 207:733-739.

13. Ahmad S, Mokaddas E, Jaber AA: Rapid detection of ethambutolresistant Mycobacterium tuberculosis strains by PCR-RFLP targeting embB codons 306 and 497 and iniA codon 501 mutations. Mol Cell Probes 2004, 18:299-306.

14. Dalwai A, Ahmad S, Pacsa A, Al-Nakib W: Echovirus type 9 is an important cause of viral encephalitis among infants and children in Kuwait. J Clin Virol 2009, 44:48-51

15. Chen B, Chen P, Jow G, Sablon E, Liu CJ, Chen DS, Kao JH: High prevalence of mixed genotype infections in hepatitis $B$ virus infected intravenous drug users. J Med Virol 2004, 74:536-542.

16. Grandjacques C, Pradat P, Stuyver L, Chevallier M, Chevallier P, Pichoud C, Maisonnas M, Trépo C, Zoulim F: Rapid detection of genotypes and mutations in the pre-core promoter and the pre-core region of hepatitis B virus genome: correlation with viral persistence and disease severity. J Hepatol 2000, 33:430-9.

17. Amini-Bavil-Olyaee S, Sarrami-Forooshani R, Adeli A, Sabahi F, Abachi M, Azizi M, Mahboudi F: Complete Genomic Sequence and Phylogenetic Relatedness of Hepatitis B Virus Isolated from Iran. J Med Virol 2005, 76:318-326. 
18. Saudy N, Sugauchi F, Tanaka Y, Suzuki S, Aal AA, Zaid MA, Agha S, Mizokami M: Genotypes and phylogenetic characterization of hepatitis B and delta viruses in Egypt. J Med Virol 2003, 70:529-36.

19. Sunbul $M$, Leblebicioglu $H$ : Distribution of hepatitis $B$ virus genotypes in patients with chronic hepatitis B in Turkey. World J Gastroenterol 2005, 11:1976-1980.

20. Magnius L, Norder H: Subtypes, genotypes and molecular epidemiology of the hepatitis B virus as reflected by sequence variability of the S-gene. Intervirology 1995, 38:24-34.

doi: 10.1186/1743-422X-7-111

Cite this article as: Ali et al., Comparative evaluation of INNO-LiPA HBV assay, direct DNA sequencing and subtractive PCR-RFLP for genotyping of clinical HBV isolates Virology Journal 2010, 7:111

Submit your next manuscript to BioMed Central and take full advantage of:

- Convenient online submission

- Thorough peer review

- No space constraints or color figure charges

- Immediate publication on acceptance

- Inclusion in PubMed, CAS, Scopus and Google Scholar

- Research which is freely available for redistribution

Submit your manuscript at www.biomedcentral.com/submit
() BioMed Central 